\title{
Social Rehabilitation Practices of Inclusion In The Educational Process In Working With Children With Disabilities
}

\section{Prácticas de rehabilitación social de inclusión en el proceso educativo al trabajar con niños con discapacidades}

Maryna O. Vasylyeva-Khalatnykova

Taras Shevchenko National University of Kyiv, Kyiv, Ukraine https://orcid.org/0000-0002-8488-4602

\section{Olena Chuiko}

Taras Shevchenko National University of Kyiv, Kyiv, Ukraine https://orcid.org/0000-0001-7088-0961

\section{Ivan S. Bakhov}

Interregional Academy of Personnel Management, Kyiv, Ukraine https://orcid.org/0000-0002-8379-199X

Valentyna Ternopilska

National M. Dragomanov Pedagogical University of Kyiv, Kyiv, Ukraine https://orcid.org/0000-0002-1468-9932

Nadiia Chernukha

Taras Shevchenko National University of Kyiv, Kyiv, Ukraine https://orcid.org/0000-0002-5250-2366

*Correspondencia

Email: i.bakhov59@gmail.com 


\section{Summary}

Coming into being and development of inclusive education in contemporary Ukrainian society are analysed. The tasks of educational institutions in creating an inclusive space are defined, and the approaches to work with children with disabilities are identified. Works of foreign and domestic scholars and practitioners who studied the problems of inclusion of children with disabilities in the educational process and in the context of social rehabilitation activities are studied. Emphasis is placed on theoretical analysis of social rehabilitation practices of inclusion. A mechanism for implementing social rehabilitation practices of inclusion in the educational process of working with children with disabilities is suggested.

Keywords: Educational Process, Inclusive Education, Disabilities, Rehabilitation, Social Care, Social Rehabilitation Model.

\section{Resumen}

Se analiza la creación y el desarrollo de la educación inclusiva en la sociedad ucraniana contemporánea. Se definen las tareas de las instituciones educativas en la creación de un espacio inclusivo y se identifican los enfoques para trabajar con niños con discapacidad. Se estudian trabajos de académicos y profesionales extranjeros y nacionales que estudiaron los problemas de inclusión de los niños con discapacidad en el proceso educativo y en el contexto de las actividades de rehabilitación social. Se hace énfasis en el análisis teórico de las prácticas de inclusión en la rehabilitación social. Se sugiere un mecanismo para implementar prácticas de rehabilitación social de inclusión en el proceso educativo de trabajo con niños con discapacidad.

Palabras clave: Proceso educativo, Educación inclusiva, Discapacidades, Rehabilitación, Atención social, Modelo de rehabilitación social.

\section{Introduction}

Definition of adequate goals in the educational process for all children, the process of eliminating barriers, creating a resource, safe and tolerant inclusive environment are the most important tasks of educational institutions, which is, in particular, the focus of social rehabilitation practices of inclusion.

\section{Analyses of publication on the issue.}

It is worth noting that scholars and practitioners who have studied problems of inclusion of children with disabilities in the educational process and at the level of social rehabilitation activities include the following foreign (Gargiulo, Metcalf, 2013; Loreman, 2010; McGhieRichmond, Underwood, Jordan, 2007; Peterson, 2010; Smith, 2008; Vaughn, Bos, 2012 and others) and domestic experts (Baida, 2013; Belousova, 2018; Davydenko, 2015a; 2015b; 2015c; Dikova-Favorska, 2016; Dobrovitska, 2019; Kolupaeva, 2019; Myskiv, 2014; Mironova, 2016; Chernukha, Vasylyeva-Khalatnykova, 2019; 2020; Efimova, Sofiy; 2006 and others).

Objective of the article. Identify the principles and conditions of social rehabilitation practices of inclusion in working with children with disabilities and the implementation of the right of children with disabilities to inclusive education. 


\section{Mathodology}

Authors suggest and substantiate the model of social rehabilitation support for children with disabilities in an inclusive educational environment.

\section{Results}

To understand the orientation of social rehabilitation practices of inclusion in the educational process when working with children with disabilities, it is necessary to have a comprehensive understanding of such concepts as "inclusion," "inclusive education" and their substantive essence.

We share the view that inclusion represents full inclusion of a child with a disability in all positive aspects of the life of an educational institution that are accessible to his/her peers (Kazachiner, 2018, p. 10).

It should be noted that the emergence of ideas of affordable education causes objective changes in connections within educational institutions, which requires unique social rehabilitation practices of inclusion.

Considering inclusive education in a narrow substantive sense, we emphasize that it means including a child with a disability in the educational process with other children to learn social experience and the existing system of social relations (Kazachiner, 2018, p. 12).

Analyzing the inclusive social rehabilitation practices in working with children with disabilities (those related to socialization; human rights protection; communication; health recovery; playing; therapy, education, awareness-building etc.) it is advisable to give accent to a number of approaches, namely desegregation of educational institutions, expansion of access to education, greater access to education, mainstreaming, integration, and inclusion.

Desegregation of educational institutions is educational reform focused on combating discrimination in accordance with the racial, gender and psychophysiological characteristics of a child. Greater access to education means an opportunity for a child with a disability to receive education. Mainstreaming is a strategy where a child with a disability communicates with peers at leisure rather than to achieve educational goals. Integration means restoring, filling, uniting parts into a whole. Inclusion means reforming educational institutions so that they meet the needs of all children without exception (Lupart, Webber, 2002, pp. 145-148).

Relying on the definition by Peter Mittler, a professor at the University of Manchester, stating that "inclusive education is the first step towards the goal of creating an inclusive society that will allow all children and adults, regardless of their gender, age, ethnicity, abilities, to fully participate in society and to make their contribution" (Petrovska, Gurenko, 2019, p. 16), we emphasize that inclusive education is not only a way of acquiring knowledge, building skills and abilities but also a process of socialization and finding one's place in society and, accordingly, theoretical substantiation and introduction into the educational environment of educational institutions of effective social rehabilitation practices of inclusion in working with children with disabilities.

Thus, the social rehabilitation practice of inclusion means providing social rehabilitation assistance to children with disabilities in the educational process in order to restore the socio-psychological, value-based and behavioral components of personality and meeting the needs of socialization. 
The right of children with disabilities to inclusive education is enshrined at the international level by the Convention on the Rights of Persons with Disabilities; the Salamanca Statement on Principles, Policy and Practice in Special Needs Education; Standard Rules on the Equalization of Opportunities for Persons with Disabilities (Convention against Discrimination in Education, 1960; Salamanca Declaration and Framework for Action on the Education of Persons with Disabilities, June 1994).

According to the letter of the MES of Ukraine №1/9-409 "On organization of inclusive education at educational institutions in the 2019/2020 academic year" (June 26, 2019); of the MES of Ukraine №1/9-495 "On organization of education of persons with special educational needs in general secondary education institutions in the 2020/2021 academic year" (August 31, 2020); letter of the MES of Ukraine №1/9-498 "Methodological recommendations on organization of training of persons with special needs at educational institutions in the 2019/2020 academic year" (August 5, 2019): “...training of a child with a disability at an educational institution is a significant stage of socialization, because it is there that their worldview and values are shaped, an individual model of relationships with peers is consolidated..."

\section{Discussion}

Recourse to analysis of the current state of practical activities at educational institutions in developing an inclusive space gives grounds for arguing that the social rehabilitation practices of inclusion in working with children with disabilities are based on such principles as:

- a person's value depends not only on his abilities and achievements;

- each person is unique;

- everyone is able to feel and reason;

- everyone has the right to communicate and to be heard;

- real educational activities can be carried out only in the context of real relationships;

and

- for all people, achievement of progress can be more in what they can do rather than in what they cannot do; diversity enhances all aspects of human life (Lupart, Webber, 2002, p. 117).

Research and analysis of recent publications of domestic scholars on building and developing an inclusive educational space in Ukraine (Belousova, 2018; Bondar, 2018; DikovaFavorska, 2016; Letter of the Ministry of Education and Science of Ukraine 1/9-495, 2020; Mironova, 2016; Petrovska, Gurenko, 2019) strengthens the position of theorists and practitioners that the priority role in the implementation of social rehabilitation practices of inclusion in the educational process in working with children with disabilities is played by the figure of the social care teacher of an educational institution. It is the social care teacher who ensures socio-cultural rehabilitation and social adaptation of children with disabilities and their families through the educational environment; monitors respect for the rights of children with disabilities and their families; and helps parents to adapt children with disabilities to the social environment. It is important to prevent phenomena of social maladjustment of children with disabilities and their families (Mironova, 2016, p. 141).

It is worth emphasizing that in organization of its activities, the social care teacher relies on contemporary philosophy of independent living of a person with a disability (Sadova, 2020, pp. 150-151) and the idea of compensatory development (Sadova, 2020, p. 151). He/she is involved in increasing the level of adaptive capabilities of a family raising a child with a disability. This capacity is formed due both to internal resources of the family and resources of the social environment. It is important for practical activities of the social care teacher to identify and mobilize internal rehabilitation potential of the family (Petrovska, Gurenko, 2019, p. 75). 
We emphasize that in the practical activities of the social care teacher at an inclusive educational institution the following tasks are the most significant: decisions;

- interaction with specialists of the educational institution in order to make collective

- development of inclusive culture with respect to children with disabilities;

- socio-pedagogical study of the family of a child with a disability, identification of its adaptive potential and capabilities;

- provision of the family of a child with a disability with a set of preventive and educational services;

- organization of various types of interaction, cooperation of the participants in the educational process, both at an educational institution and outside it;

- creation of mutual assistance groups for families with a child with a disability;

- preventive informational support for families with a child with a disability;

- emergency social support;

- performance of social advocacy functions; and

- prevention of addictions in the family of a child with a disability (Petrovska, Gurenko, 2019, pp. 78-79).

In the process of implementing social rehabilitation practices of inclusion, the social care teacher, starting work with a child with a disability, examines the socio-pedagogical problems of the family paying special attention to such important indicators as:

- financial situation of the family;

- general culture of the family;

- socio-psychological climate in the family;

- rehabilitation culture and social activity of the members of a family of a child with a disability; and

- family's attitude to educational and social rehabilitation problems of a child with a disability (Chen, Heritage, Lee, 2005, pp. 65-67).

In addition to the above, the indicators also provide for the following: studying appeals of the parents of a child with a disability for socio-pedagogical assistance; taking into account the socio-demographic and socio-economic aspects of the life of a family of a child with a disability; identifying socio-pedagogical expectations of the family of a child with a disability; assessing the mode of life: its behavioral, emotional, and cognitive components; identifying emerging socio-pedagogical problems, analyzing objective and subjective causes of their manifestations; identifying internal rehabilitation resources; determining the external resources of the family of a child with a disability; and helping the family to socialize and expand the sociocultural space (McGhie-Richmond, Underwood, Jordan, 2007, p. 73). 
Note that an inclusive approach in education is indicative of a transition to a social model that maintains: the cause of disability does not lie in the disease itself as such; the cause of disability lies in the barriers, stereotypes, and prejudices existing in society (Petrovska, Gurenko, 2019, p. 31).

The above is strengthened by the provisions of the new version of the Law of Ukraine "On Social Services" N 2671-VIII (January 17, 2019), which clearly set out the basic social services in contemporary Ukrainian society. Accordingly, social rehabilitation services in working with a child with a disability are based on generally accepted social services prescribed by law.

As shown in theoretical analysis of a number of academic papers (Belousova, 2018; Bondar, 2018; Dikova-Favorska, 2016; Letter of the Ministry of Education and Science of Ukraine 1/9-495, 2020; Lupart, Webber, 2002; Giangreco et al., 1993), social rehabilitation practices of inclusion in working with children with disabilities at an educational institution can be systematized as pertaining to: socialization, human rights protection, communication, health recovery, playing, education, and awareness-raising.

Socializing social rehabilitation practices are focused on the process of adaptation, integration and socialization of children with disabilities at an educational institution. They are implemented in the form of both individual and group work. We can mention the following as the most interesting: mentors' club, special interest clubs, leadership development center, tolerance weeks, self-help groups for children with disabilities and their parents, etc. For example, an event as part of a tolerance week aimed at the disseminating information on the topic: "cerebral palsy and the environment."

Human rights protection-related social rehabilitation practices -- legal education and protection of the rights and freedoms of a child with a disability and his/her family, creation of a safe environment for the child. They are usually implemented with the involvement of a school resource officer. It is possible to distinguish educational lecture courses, discussions, videos on the rights and freedoms of children, in particular, children with disabilities, socio-pedagogical training sessions, counselling interviews with teachers and parents of children with disabilities, theme weeks etc. For example, an educational lecture course for parents of children with disabilities on the rights and freedoms of children at an educational institution (Taranchenko, Naida, 2012).

Communicative social rehabilitation practices are focused on building nonviolent communication of teachers, children, and parents; restoration of the moral and psychological climate; and development of communicative competencies of a child with a disability. We can mention among them debating clubs, marathons, quests; school volunteer movement, communicative debates etc. For example, communicative debates among children on the topic "Ecology: realities and prospects."

Health recovery-related social rehabilitation practices are those providing for measures aimed at maintaining and restoring the mental and physical health of a child with a disability at an educational institution. There are health theme days, bullying and cyber-bullying preventive activities, educational lecture courses and debates etc. For example, an educational lecture course on "Disability and Sports."

Play-based social rehabilitation practices represent recreational (leisure) activities focused on recovery and recreation of a child with a disability at an educational institution. It is possible to note the following: art-therapeutic activities (drawing, origami, and clay modelling); sports thematic marathons, quests, and physical exercises; extracurricular creative centres etc., for example, an origami master class on the topic "Happiness." 
Educational social rehabilitation practices are those focused on identifying educational capabilities of children with disabilities and training of teachers and parents. We will note among them thematic lectures, video films, meetings with experts concerning training of children with disabilities for teachers; psychological and social diagnostics of educational opportunities of children with disabilities etc. Educational social rehabilitation practices provide for the work of an interdisciplinary team (social care teacher, speech therapist, psychologist, school resource officer, and outside experts). For example, a lecture course for teachers on the topic "Children with Down's syndrome: stage-by-stage acquisition of mathematical knowledge in the first grade."

Awareness-building social rehabilitation practices represent measures aimed at enlightening teachers, children and parents about inclusion at educational institution. We can distinguish among them handouts, lecture course, video lecture courses, thematic channels on social networks etc. For example: video lessons on the Braille alphabet on the TikTok channel.

It should be noted that inclusive social rehabilitation practices in working with children with disabilities are practically implemented in a staged manner. The stage of studying the real state of a problem (monitoring, diagnostics) is an important step in implementing inclusive social rehabilitation practices in working with children with disabilities (Petrovska, Gurenko, 2019, pp. 132-134). In the course of diagnostics and monitoring, the degree of inclusion of a child with a disability in a team of peers, the possibility of its acceptance by peers in educational and extracurricular activities is determined.

Note that the main method of diagnosing and monitoring in inclusive social rehabilitation practice consists in observation of a children's collective; of a child with a disability; of involvement of parents of children with disabilities in educational and extracurricular activities. Various methods of observation are used, namely of those engaged in socio-pedagogical support for children with disabilities; of a children's team; of parents etc. Among the methods of diagnosis and monitoring in inclusive social rehabilitation practice it is also appropriate to highlight. It is also advisable to mention the following among the diagnosing and monitoring methods in inclusive social rehabilitation practice:

- studying biographical data of the family of a child with a disability;

- surveying parents, teachers, and peers; and

- projective techniques studying families and children with disabilities (Peterson, 2010, p. 88).

It should be taken into account that the principles of diagnosing and monitoring are, first of, as follows: complexity, comprehensive orientation, systemacity, objectivity, consistency, identification of intellectual potential of families and children with disabilities etc (Loreman, 2010, pp. 86-87).

In this process, techniques focused on studying school communities, parent-child relationships are used; defining the main strategies of behavior of educational space actors; the nature of communications in the family and at the educational institution and so on.

Let us remark here that just in inclusive social rehabilitation practice in working with children with disabilities one can choose a certain (optional) diagnostic suite that identifies the structural-functional type of families; its socio-pedagogical diagnosis; social passports of families, classes, educational institutions and so forth.

It is worth noting that on the basis of diagnosing and monitoring inclusive social rehabilitation practice, its next stage is formed -- activity planning (Gargiulo, Metcalf, 2013, p. 
89). Activity planning involves provision of targeted assistance to participants in the educational process with the assistance of specialists (speech therapist, psychologist, school resource officer etc.). A targeted plan for work with a family, with a child with a disability and his/her peers is developed being aimed at integration into the school environment and socialization of a child with a disability. Opportunities for interaction with institutions in the area of social support, with nongovernmental organizations that protect the rights of children with disabilities, out-ofschool education institutions regarding establishment of parents' clubs or parents' associations of children with disabilities are identified based on information collected etc.

As to the content and structure, we deem it advisable to emphasize that in the process of implementing inclusive social rehabilitation practices there are short-term and long-term forms of social rehabilitation support for children with disabilities. Short-term forms of sociopedagogical support include crisis and problem-oriented ones. The crisis form of social rehabilitation support represents the initial stage of working with a family and a child with a disability providing for a quick response in a crisis situation. In case of the problem-oriented form, working with a family and a child with a disability concerns a specific problem.

According to scientific publications on theory and practice of social work (Chernukha, Vasylyeva-Khalatnykova, 2020; Gargiulo, Metcalf, 2013; McGhie-Richmond, Underwood, Jordan, 2007), long-term forms and, in particular, inclusive social rehabilitation practices are based on the psychosocial approach. Interaction with the family of a child with a disability rests on simultaneous change of the family system and of its functioning in a positive direction toward performance of the functions of sociocultural development and adaptation of the child with a disability (Chernukha, Vasylyeva-Khalatnykova, 2020, pp. 61-62).

It is worth emphasizing that in the event that a family with a child with a disability is not motivated to apply for social rehabilitation assistance for the child with a disability, differently vectored inclusive social rehabilitation practices are used depending on the specific situation: socializing; human rights protection-related; communicative; health recovery; playbased; therapeutic, educational, and awareness-building.

As part of modern social rehabilitation practices of inclusion in working with children with disabilities, the use of the model of social rehabilitation support for a child with a disability in the educational process is quite effective.

The above substantive and structural characteristic of the differently vectored social rehabilitation practices are logically embedded in the model of holistic and comprehensive social rehabilitation support for a child with a disability in an inclusive educational environment and includes structural-organizational and substantive-procedural specifics of this process. The model can be presented as follows (Figure 1):

Figure (1): Model of social rehabilitation support for children with disabilities in an inclusive educational environment 


\section{Model of social rehabilitation support for children with} disabilities in the educational process

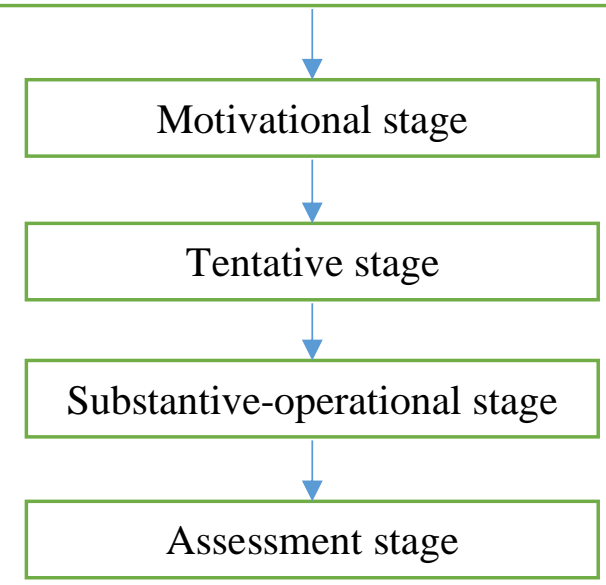

Motivational stage - ensuring a favorable socio-psychological climate for implementation of the process of supporting and creating motivation for future activities in all participants in the educational process. Social rehabilitation work depends on the nature of relationships in the teacher-child-parents triad. Only in case of creation of a resource environment and concerted action of all participants in the educational process is it possible to implement an effective process of social rehabilitation. The motivational stage largely depends on personal qualities and professionalism, on how convincingly the strategy of social rehabilitation is set out.

Tentative stage consists in defining the purpose and content of future activities, working out a general approach, defining the roles and professional positions concerning children with disabilities, and dividing functional responsibilities among the participants of social rehabilitation support. At this stage, the structural elements of social rehabilitation support are detailed (identifying causes of complications, school maladjustment of children with disabilities; substantiating the content of social rehabilitation work and forms of its performance; choosing ways to organize this process taking into account the resources of a child with a disability and capabilities of the adults involved in providing social rehabilitation support; and finding out the opinion of the parents about the problems of the child with a disability and the expected results). The social rehabilitation process will be carried out in a real situation of training a child with a disability. A concept of social rehabilitation support is developed, and requirements to the social environment within the family are established.

The substantive-operational stage consists in developing social rehabilitation programs on a diagnostic basis for a child with a disability regarding accomplishment of specific tasks. The social care teacher works together with the psychologist, the speech therapist, the teacher, and the parents for the purpose of their interaction.

The assessment stage includes final social rehabilitation diagnostics, analysis of the results by all specialists, and reflection. The degree of satisfaction of the parents of a child with a disability, their wishes for the future are taken into consideration. Summing-up can serve as a basis for further work (Chernukha, Vasylyeva-Khalatnykova, 2020, pp. 101-114).

\section{Conclusion}

Thus, research and analysis of social rehabilitation practices of inclusion in the educational process when working with children with disabilities suggest that the current social rehabilitation practices of inclusion undoubtedly provide answers to a number of today's challenges. However, they need further modernization and optimization, commitment to the best 
domestic and foreign practices, as well as the use of innovations in practical activities of the social sector.

\section{References}

Baida, L.Yu. (2013). Training module "Interdepartmental approach in the implementation of inclusive education". Canadian-Ukrainian project "Inclusion. education for children with special needs in Ukraine". Kiev.

Belousova, N.V. (2018). Inclusive tourism in the system of rehabilitation geography: from theory to practice: monograph. Kyiv: Kyiv National Aviation University.

Bondar, T.I. (2018). Inclusive education in the USA and Canada: development trends: monograph. Cherkasy National University Bohdan Khmelnytsky. Cherkasy: Tretyakov O.

Chernukha, N., Vasylieva-Khalatnykova, M. (2020). Model of social and pedagogical support of children with disabilities in the educational process. Relevant Issues of the Development of Science: Collective monograph. San Antonio.

Convention against Discrimination in Education. (1960). UN High Commissioner for Human Rights. United Nations.

Davydenko, G.V. (2015). Inclusive education of persons with disabilities in the system of higher education of Ukraine: collective monograph. Vinnytsia: Nilan.

Davydenko, G.V. (2015a). Conditions for the implementation of inclusive education in higher education institutions of the European Union (psychological, mental, social and organizational aspects): textbook. Vinnytsia: Nilan.

Davydenko, G.V. (2015b). Inclusion in higher educational institutions of the European Union: monograph. National Aviation University. Vinnytsia: Nilan.

Dikova-Favorska, O.M. (2016). Inclusion in education: everyday practice and evaluation procedure: monograph. Kyiv: NPU Publishing House M.P. Dragomanova.

Dobrovitska, O.O. (2019). Preparation of future social workers for tolerant interaction in an inclusive environment: thesis abstract. Slavyansk.

Efimova, S., Sofiy, N. (2006). Inclusive education: The Step-by-Step program influencing children, teachers, parents and state policy in Ukraine. In R. Stake (Ed.). Multiple case study analysis. New York: The Guilford Press.

Gargiulo, R.M., Metcalf, D. (2013). Teaching in today's inclusive classrooms: a universal design for learning approach. Belmont: Wadsworth, Cengage Learning.

Giangreco, M.F., Dennis, R., Cloninger, C., Edelman, S., Schattman. (1993). «I've counted Jon»: Transformational experiences of teachers educating studenrs with disabilities. Exceptional Children, 59(4): $359-372$.

Kazachiner, O.S. (2018). Inclusive education in English-speaking countries: a manual. Kharkiv: Osnova.

Kolupaeva, A.A. (2019). Inclusive education: realities and prospects: Monograph. Kyiv: "Summit - Book".

Law of Ukraine N 2671-VIII. (January 17, 2019). "On social services". Retrieved from: http://search.ligazakon.ua/1_doc2.nsf/link1/TM062548.html

Letter of the Ministry of Education and Science of Ukraine 1/9-409. (June 26, 2019). "On the organization of inclusive education in educational institutions in $2019-2020$ academic year". Retrieved from: https://osvita-perechin.gov.ua/uploads/1_9-409sodo-organizacii-inkluzivnogo-navcanna-u-zakladah-osviti-u-2019-2020-n.-r..pdf

Letter of the Ministry of Education and Science of Ukraine 1/9-498. (August 5, 2019). "Methodological recommendations for the organization of training of persons with special needs in educational institutions in 2019-2020 academic year". Retrieved from: https://osvita-perechin.gov.ua/uploads/metod-rekomend-nav-ditej-z-OOP06.08.2019.pdf

Letter of the Ministry of Education and Science of Ukraine 1/9-495. (August 31, 2020). "On the organization of education of persons with special educational needs in general secondary education institutions in the 2020/2021 academic year". Retrieved from: 
https://osvita-perechin.gov.ua/uploads/luct_MONU_No_1_9-495-metodicnirekomendacii-inkluzia.pdf

Loreman, T. (2010). Inclusive education: Supporting diversity in the classroom. London and New York: Routledge.

Lupart, D., Webber, C. (2002). School reform in Canada: the transition from separate education systems to inclusive schools. Exceptionality Educatoion Canada, 12(2): 752.

McGhie-Richmond, D., Underwood, K., Jordan, A. (2007). Developing Effective Instructional Strategies for Teaching in Inclusive classrooms. Exceptionality Education Canada, 17(1/2): $27-52$.

Mironova, S.P. (2016). Pedagogy of inclusive education: teaching method. way. KamyanetsPodilsky: Kamyanets-Podil Ivan Ogienko National University.

Myskiv, L.I. (2014). Legal problems of inclusive education in Ukraine: monograph. Kharkiv: NikaNova.

Peterson, M.J. (2010). Inclusive teaching: The journey towards effective schools for all learners. Boston: Pearson Education, Inc.

Petrovska, K., Gurenko, O. (2019). Socio-educational dominants of professional training of specialists in the social sphere and inclusive education: Social-educational dominants of specialist's professional preparation of social sphere and inclusive education: materials of All-Ukrainian scientific-practical Internet conference, October 23-24. 2019. Berdyansk State Pedagogical university. Berdyansk. BSPU.

Sadova, I. (2020). Inclusion in institutions of general secondary education of Ukraine: development trends: monograph. Drohobych: Posvit.

Salamanca Declaration and Framework for Action on the Education of Persons with Disabilities. (June 1994). World Conference on Education of Persons with Disabilities: Access and Quality, Salamanca, Spain. UNESCO. Retrieved from: https://zakon.rada.gov.ua/laws/show/995_001-94\#Text

Smith, T.E. (2008). Teaching students with special needs in inclusive settings. Boston: Pearson Education, Inc.

Taranchenko, O.M., Naida, Yu.M. (2012). Differentiated teaching in an inclusive educational institution: a textbook. Kyiv: ASK Publishing Group.

Vasilieva-Khalatnikova, M.O. (2019). Pedagogical conditions and features of the sociocultural environment of inclusion in the institution of general secondary education for children with disabilities. Advanced trends of the modern development of psychology and pedagogy in European countries: Collective monograph. Riga: Izdevnieciba «Baltija Publishing».

Vaughn, S., Bos, C.S. (2012). Strategies for teaching students with learning and behavior problems. New Jersey: Pearson Education, Inc.

Chen, E., Heritage, M., Lee, J. (2005). Identifying and monitoring students' learning needs with technology. Journal of Education for Students Placed at Risk, 10: 309 - 332. 